\title{
War pensions schemes: at the root of a set of medico-legal criteria as current as ever
}

\author{
Natale Mario di Luca, ${ }^{1}$ Gianluca Montanari Vergallo \\ ${ }^{1}$ Full Professor of Legal Medicine, Faculty of Pharmacy and Medicine, "Sapienza" University of Rome; ${ }^{2}$ Assistant \\ Professor of Legal Medicine, Faculty of Pharmacy and Medicine, "Sapienza" University of Rome, Italy
}

\begin{abstract}
The following report has been devised in an attempt to address and elaborate on the medico-legal assessment criteria applicable to warrelated damages, in light of the Presidential Decree n. 915, $23^{\text {rd }}$, December 1978, by drawing comparisons among workplace-injury legislation, welfare systems, and the conventional standards within medico-legal doctrine. Among the elements herein analyzed: a) analytical criteria, expecting an overhaul and thorough implementation of injury case records; b) quality and quantity-related adjectivization such as «grave» and «remarkable»; c) the irrelevance of residual functional capabilities that do not provably affect one's capacity to successfully engage in any given type of work; d) the assessment of multiple, permanent impairment instances, whether they be homogeneous, heterogeneous, monocrone (i.e. arising from a single event), policrone (resulting from multiple events), concurrent or coexisting; e) the definition of organ; f) the concept of paired organs; g) partial loss of the left-over organ. The paper's authors ultimately highlight the enduring quality of the medico-legal criteria inherent to the legislation at hand, which, however, ought to be overhauled and updated in order to better reflect the conceptual developments that have occurred with regards to damage compensation in tort law and workplace injuries and occupational disease, which have given rise to the concept of biological damage as a basic one, worthy of redress in itself, regardless of further workrelated consequences.
\end{abstract}

\section{RIASSUNTO}

Il presente contributo analizza i criteri medico-legali di valutazione del danno patito a causa della guerra alla luce del decreto del Presidente della Repubblica n. 915 del 23 dicembre 1978, operando un raffronto sia con i criteri previsti dalle leggi in materia di infortuni sul lavoro e di previdenza sociale sia con le tradizionali acquisizioni della dottrina medico-legale. In particolare, vengono analizzati: a) il criterio analogico, auspicando la revisione e l'adeguata implementazione della casistica delle menomazioni; b) le aggettivazioni qualiquantitative, come «grave» e «notevole»; c) l'irrilevanza di quelle residue capacità funzionali che non presentino alcuna utilità agli effetti della capacità a proficuo lavoro; d) la valutazione delle menomazioni plurime a carattere permanente, a seconda che siano omogenee, eterogenee, monocrone, policrone, concorrenti o coesistenti; e) il concetto di organo; f) la nozione di organo pari; g) la perdita parziale dell'organo superstite. Gli autori concludono evidenziando la perdurante qualità dei criteri medico-legali previsti dalla normativa in esame, la quale, tuttavia, dovrebbe essere aggiornata per tenere conto dell'evoluzione concettuale intervenuta in sede sia di risarcimento del danno in responsabilità civile sia di infortuni sul lavoro e di malattie professionali, che ha introdotto la nozione di danno biologico quale danno di base, già di per sé meritevole di tutela indipendentemente da ulteriori conseguenze di carattere lavorativo e lucrativo.

\section{RESUMEN}

Este trabajo analiza los criterios médico-legales para evaluar el daño sufrido como resultado de la guerra a la luz del Decreto Presidencial n. 915 del 23 de diciembre de 1978, haciendo una comparación tanto con los criterios establecidos por las leyes sobre accidentes de trabajo y seguridad social como con las adquisiciones tradicionales de doctrina médico-legal. En particular, se analizan: a) el criterio analógico, esperando la revisión y la implementación adecuada de la casuística de impedimentos; b) adjetivos cualitativo-cuantitativos, tales como "serio" y "notable"; c) la irrelevancia de las capacidades funcionales residuales que no presentan ninguna utilidad para los efectos de la capacidad de trabajo rentable; d) la evaluación de impedimentos permanentes múltiples, según sean homogéneos, heterogéneos, monocromados, policromados, concurrentes o coexistentes; e) el concepto de un órgano; f) la noción de un órgano igual; g) pérdida parcial del órgano superviviente. Los autores concluyen destacando la calidad continua de los criterios médico legales establecidos por la legislación en cuestión, que, sin embargo, deberían actualizarse teniendo en cuenta la evolución conceptual que se produce tanto en la indemnización por daños en la responsabilidad civil como en los accidentes de trabajo y enfermedades profesionales, que introdujo la noción de daño biológico como un daño básico, que ya en sí mismo merece protección, independientemente de otras consecuencias lucrativas y relacionadas con el trabajo.

Special legislation centered on war pension schemes has historically undergone an evolution that appears to be "separate" from the norms governing other kinds of welfare and pensionrelated systems in Italy, however circumscribed and ascribable to precise categories they may be; nonetheless, each and every one of such systems, including the one highlighted herein, is centered on the need to bring remedy to socially and economically adverse circumstances, which are begotten by non-individual, generalized events affecting society as a whole, on a national level.

"War" as an anthropological phenomenon - the continuation 
of politics by other means, in the definition of Carl von Clausewitz ${ }^{1}$ - entails an array of events with an extremely high degree of destructiveness in terms of material damage and, even more so, from the clinical and medico-legal perspectives, affecting human lives as well as psycho-physical integrity possibly to the extent of total annihilation of entire communities through nuclear weapons, as occurred at the end of the Second World War, whose eventual alleged ban as a result of international treaties has not staved off the breaking out of countless conflicts over the next seven decades, however circumscribed and varying in intensity, but very often indiscriminately affecting the lives of civilian populations, irrespective of age and gender.

It cannot therefore be reasonably stated that the originals motives at the heart of war pension systems have nowadays ceased to exist, or that the application of such safeguards can be limited to marginal or indirect cases. Yet another issue arising from the despicable but recurring breaking out of armed conflicts, whether they be for defensive purposes, as sanctioned by the Constitution of the Italian Republic (articles 11 and 52), has to do with information criteria and interventional tools as to the welfare safeguards themselves, which must be duly overhauled and effective.

A thorough appraisal of information criteria - which is at the center of this paper's analysis - should closely focus on the fundamental principle known as "presumptive origin" (caused by war events) of any injury, lesion or impairment directly stemmed from or exacerbated by combat-related activities (while imprisoned by enemy forces, for instance), or having contracted epidemic or infectious diseases while discharging one's military duties in wartime or war-related services.

As far as civilians are concerned, the presumptive war origin is somehow subdued by the requisite element known as "derivation of impairment", or its worsening, or even violent, direct and immediate death. Lastly, it is worth mentioning the presumption of death for those disappeared or missing in war theaters.

This paper is not meant to be delving into the wide range of possible assumptions comprised within the legal codes, or the issues related to causal relationship, with reference to the above mentioned violent death, which are partly identifiable with those covered in article 2 of Presidential Decree 1124/1965 and article 1223 of the Italian Civil Code. However, it is worth stressing that the presumption of causation in war theaters has been widely applied, thus lifting the burden of proof, whose conventional legal standards would be mostly impossible to meet under such conditions, from victims, on political and legal grounds developed over time on account of adverse events interconnected with employment circumstances.

Moreover, it is noteworthy how widespread a use has been made of the chart-based system, broken down by categories of anatomical dysfunctions in descending order and considered uniform within each category. The choice to adopt a scale-based system in assessing presumptive injuries is akin to the listing system of workplace injuries, which was designed at roughly the same time, although the former has taken up simplified criteria in compiling the charts, as opposed to percentage-based figures and data for the latter. It is worth noting that within the wider welfare system run by the Italian national welfare agency I.N.P.S. (the National Social Welfare Institute), the choice by lawmakers was, to this day, to defining the impairing effects, while disregarding possible biological and clinical causes and their nosographic analysis.

Aspects related to the legal classification of effects, intended as «loss or impairment of overall working capabilities» (art. 2 of Presidential Decree n. 915, 23 ${ }^{\text {rd }}$ December 1978, ) arguably appear to be outdated elements as opposed to an evolution of key assessment criteria that have occurred in tort law and damage compensa- tion, as well as pertaining to workplace injuries and occupational diseases; such innovations have paved the way for the notion of biological damage as ensuing consequence, which is deemed worthy of safeguards irrespective of further repercussions in terms of lost or reduced ability to be gainfully employed.

It has been almost forty years since the work safety act was passed into law, and in light of the above mentioned legal evolution, the times are likely ripe for a harmonization of all different levels of protection revolving around the biological damage standards of appraisal.

We shall now focus on the aspects relative to those criteria that make up the current set of norms, as it developed from its inception.

The application of analytical or equivalence standards (art. 11, $4^{\text {th }}$ subsection, of T.U. $)^{2}$ was made necessary by the adoption of the table-based system of impairment categories, whose limit lies with the impossibility to comprise therein each and every kind of impairment hypothesis, however detailed and wide-ranging the listing may be. In fact, the 202 impairment descriptors in table A, (Presidential Decree n. 834, 30 ${ }^{\text {th }}$ December 1981) are still far from constituting an exhaustive pool, although their overall number was increased compared to previous listings, and the same holds true for the 387 listings (I.N.A.I.L., Ministerial decree 12 $12^{\text {th }}$ July 2000) and for the 928 definitions laid out in the most recent guidelines for personal damage assessment in tort law (Linee guida per la valutazione del danno alla persona in ambito civilistico) devised by the Italian Society of Legal and Insurance Medicine (S.I.M.L.A.). It is worth considering future prospects for overhauling and implementing impairment-assessing case listings that would encompass any new relevant knowledge of somatic or psychological disorders, as well as the remarkable evolution of nosographic models occurred over a four-decade period, particularly in psychiatry.

The relevance of proper qualitative and quantitative adjectivization should not be overlooked, as in «grave» and «noteworthy» - in order to characterize the severity of any given damage as related to the matching impairment to which such damage is to be ascribed. As general and non-specific as such characterizations may be, they still constitute a useful set of rating standards from the diagnostic and evaluation standpoints.

Furthermore, medico-legal doctrine acknowledges the principle of "dropping functionality", «which entails the "thorough, total or complete" loss of function in a given organ, regardless of any residual functionality that do not however contribute in any measure to the individual's ability to be gainfully employed».

The following clarifications are to be deemed just as befitting medico-legal standards:

- «amputations are classified in table A, with the presumption that there is a sufficient degree of functionality and tropism left in the residual parts of the affected limb, the contralateral limb and for the lower limbs and spine»;

- «the classification is directly proportional to the scope of functional deficiency stemming from scars, aftermath of fractures, nerve lesions of the above mentioned body parts»;

- «total loss of a finger or toe is to be intended as including all phalanxes that make it up».

Clausewitz C. (von), Della Guerra, Milano, Mondadori, 1997.

Art. 11, fourth subsection, of Presidential Decree, n. 91523 December 1978: «4. All impairments not explicitly specified in tables A and $\mathrm{B}$ are to be ascribed to categories that comprise equivalent impairments taking into account application standards within tables $\mathrm{A}$ and $\mathrm{B}$ herein enclosed». 
It is necessary to delve further into the more complex and - let it be said - contentious aspects among the assessment criteria laid out in articles 16-19 of the workplace safety act, which are meant to regulate the issue of multiple, permanent impairments ${ }^{3}$.

Different legal trends that have been espoused by judicial and medico-legal doctrine on the subject can be narrowed down to three:

- Negativistic, which limits the scope of personal damage compensation - whether compensatory or indemnity payments - to the direct consequences of the legally relevant occurrence, barring the additional causes related to the injury or impairment, even those who played a role in the occurrence of the event itself;

- Integralistic, which, on the contrary, leads to the inclusion of redress of damage causal consequences relative to the main event, which thus constitute the "primum movens" (primary cause), drawing no distinction between the contributing causes of the event and of the ensuing damage;

- Proportionality principle, lying somehow at an intermediate stage between the previous ones, encompasses an element of concausal contribution over the various phases that lead to the legally relevant event and eventually climax with the creation of permanent damage.
The adoption of a principle of equivalence of causes (known as condicio sine qua non or par condicio theory) within the framework of the Italian criminal justice system (1930), and eventually acquired and applied in tort law, insurance and welfare regulations, as well as service causality has led to the prevalence of a proportionality-based trend, as mentioned above, and the ensuing distinctions in terms of multiple impairments, characterized on a cases by case basis as homogeneous or heterogeneous, with regards to the legal qualification of the original one, monocrone or policrone, in reference to the occurrence of the first one, and lastly concurrent or coexistent, based on the existence of mutual functional correlation among organic systems in which different impairments impact a single individual.

The regulations governing war pension schemes, in addition to those relative to duty causes, have over time leaned towards the proportionality-based approach, albeit with exceptions, just as it happened with regards to workplace injury laws, in which a shift has taken place towards a somewhat more integralistic approach (see article 45 of workplace injury act 1124/1965, eventually amended by law n. 780, article 4, $27^{\text {th }}$ December 1975 on the appraisal of cardiovascular complications from silicosis and asbestosis).
3 Art. 15 Payments to be granted to the majorly disabled 1. In addition to pensions or temporary payments, the disabled stricken with injuries or impairments listed in table $\mathrm{E}$, herein enclosed, are entitled to "major disability payments", which are not convertible (not payable to survivors after the beneficiary's death), to the extent laid out in the table itself.

2. A supplemental monthly check, not convertible, (totaling half of checks due to the majorly disabled indicated in table $\mathrm{E}$, letter $\mathrm{H}$, in addition to pension or temporary compensation), is due to those disabled individuals suffering from injuries or single or multiple impairments entitling them to class A pensions yet not comprised in table E.

Art. 16 Supplemental payments granted to those deemed $1^{\text {st }}$ class disabled due to the coexistence of impairments and mutilations stemming from war-related duty

1. In instances in which $1^{\text {st }}$ class disability within table A coexist along with other forms of impairment, the disabled individual is owed a payment for multiple disabilities, not convertible, in compliance with the provisions in the enclosed table $\mathrm{F}$.

2 . When impairments ascribable to $1^{\text {st }}$ class are in addition to other disability conditions, supplemental payments encoded in the previous subsection, are to be determined on the basis of the category worked out from all the multiple conditions as a whole, in accordance with table F-1 herein enclosed. Any possible differences, quantified in tenths, as specified in first subsection of article 17, derived from the application of criteria delineated in table F-1, shall be figured out on the basis of supplemental payment standards in table $\mathrm{F}$, on account of the coexistence of $1^{\text {st }}$ class and $2^{\text {nd }}$ class impairments respectively.

3. When two or more major impairments, all classified as $1^{\text {st }}$ class, with or without major disability payments granted, all impairments in addition to the condition entitling the individual to the war pension, shall be taken into account, in conformity with the herein enclosed table $\mathrm{F}$.

4. Supplemental checks for coexisting impairments shall be added to those due for major disability, even when said disability stems from multiple conditions.

Art. 17 Pension schemes and supplemental welfare checks due to those stricken with multiple coexisting conditions or amputations, belonging to categories below the first one, originated from war-related events

1. Whenever $2^{\text {nd }}$ class conditions coexist with other minor ailments, which are not deemed severe enough to be qualified as $1^{\text {st }}$ class impairment according to table F-1, an additional compensa- tion is granted, not convertible, to an amount no higher than five tenths or lower than two tenths of the difference between $1^{\text {st }}$ and $2^{\text {nd }}$ class impairment pensions, which are due to the disabled citizens in proportion with the degree of severity of their minor coexisting impairments, in conformity with information standards set forth in table F-1.

2 . Whenever $2^{\text {nd }}$ class impairments coexist with other conditions falling within $5^{\text {th }}$ class, a $1^{\text {st }}$ class pension settlement is granted in conformity with provisions set forth in table F-1.

3 . In presence of $2^{\text {nd }}$ class disabilities coexisting with other conditions ascribable to $4^{\text {th }}, 3^{\text {rd }}$, or $2^{\text {nd }}$ classes, the disabled citizen shall be granted $1^{\text {st }}$ class pension, in conformity with table F-1, in addition to a supplemental form of compensation due to multiple impairments laid out in table $\mathrm{F}$, on account of the coexistence of $8^{\text {th }}, 7^{\text {th }}$ and $8^{\text {th }}$ class disabilities respectively.

4. For those instances in which two impairments or amputations ranging from $3^{\text {rd }}$ to $8^{\text {th }}$ class in table A coexist, veterans are due to be granted pension settlements according to the class resulting from the overall scope of such impairments, in accordance with the indications in table F-1.

Art. 18 Overall assessment criteria when more than two conditions are found to coexist

1. In all cases in which there shall be an overall assessment of more than two impairments, each one of which is ascribable to table A classes, such an assessment shall be made by adding to the most severe condition the total resulting by all the others bundled together, starting from the least severe ones, figured out in conformity with criteria set forth in table F-1, enclosed herein.

Art. 19 Total or partial loss of left-over organ

1. When military personnel members or civilians, who had already sustained the anatomical or functional loss of a paired organ for reasons unrelated to war, lose the left-over organ, the pension settlement or compensation payment shall be determined on the basis of the impairment class arising from the loss or damage to both paired organs.

2. The same settlement is due to those impaired veterans who come to lose, for reasons unrelated to war, the left-over organ, whether partially or totally, after being granted war pension settlements on account of anatomical or functional organ loss.

3. In cases of loss of limbs, provisions laid out in previous subsections are to be applied even in cases of homolateral o contralateral limbs of different functions, in compliance with application standards in tables $\mathrm{A}$ and $\mathrm{B}$ enclosed within the legislation. [Omissis] 
As far as homogeneous impairments are concerned, whether policrone and monocrone, articles 16-18 of Act n. 915/1978 mandate the application of Table F-1, enclosed to the same act, that is based, as proven before ${ }^{4}$, on the Balthazard formula for combining disability values, recommended by conventional doctrine and several sets of norms ${ }^{5}$ for the evaluation of multiple homogeneous coexisting impairments. In other words, the enunciation of concauses of impairment laid out in the legislation does not enable a more effective evaluation of concurrent impairments, applying the same standards of evaluation as those applicable to coexisting impairments.

An exception to this rule is accounted for, somewhat paradoxically, in article 19 of the workplace injury act pertaining to cases of multiple heterogeneous impairments (obviously policrone ones) hat entail loss of organs, whether partial or total, of the left-over organ (in case of paired organs), equating such organ to homolateral and/or contralateral limbs, to be verified through medico-legal assessment and monetary compensation determined on the basis of the category of the total impairment that stemmed from the damage to both organs: as if the overall scope of the impairment were legally even, on the basis of an implicit, however blatant, affirmation of the concept known as "dysfunctional concourse".

It is worth hinting, in the closing remarks, on the notion of "concourse", which is laid out in the bill n. 915/1978 and further developed in an appendix to the same bill (Criteri per l'applicazione delle tabelle, table application standards $\mathrm{a}, \mathrm{b}$ and $\mathrm{e}$, letter f), wherein the following evaluation and defining criteria are spelled out:

- «The term "organ" encompasses a wide array of anatomical elements, as structurally different as they may be, while still forming a functioning compound, since they all contribute to the fulfillment of a given function (the visual and hearing systems on one side as opposed to the contralateral part; a limb).».

- " "Paired organs" are intended as a couple of the above mentioned unitary complexes, which are matched not only in their positioning, but especially from the anatomical, functional and physiopathological perspectives (e.g.: the visual or hearing systems on one side as opposed to the other)».

- «The definition "partial loss" of the left-over organ is intended as a permanent damage, whether it be anatomical or functional, of the organ itself».

- «Any organ system that offsets the loss of another one is to be deemed a "paired organ" (hearing or feeling functions, for instance, in cases of total, permanent blindness)».

\section{Correspondence: Gianluca Montanari Vergallo.}

E-mail: gianluca.montanarivergallo@uniroma1.it

Key words: War pension schemes; personal injury; medico-legal assessment standards.

Parole chiave: Pensionistica di guerra; danno personale; norme di valutazione medico-legale.

Palabras clave: Planes de pensiones de guerra; daño personal; normas de evaluación médico-legal.

Received for publication: 7 September 2017.

Revision received: 10 November 2017.

Accepted for publication: 25 November 2017.

(C)Copyright N.M. di Luca and G. Montanari Vergallo, 2017

Licensee PAGEPress, Italy

Rivista di Psicopatologia Forense, Medicina Legale, Criminologia 2017; 22:35-38
The above mentioned definition of organ is thoroughly accurate from a technical standpoint. Yet, the explanatory remark is patently inaccurate and misleading, since the medical notion of organ, legally intended, cannot be circumscribed to either "one side", but rather comprises all bilateral anatomical structures, in cases of "paired organs", instrumental to the fulfillment of any organic function; the same reasoning applies to the notion of "paired organ" as laid out in the following definition.

Lastly, in reference to the fourth definition, it is to be inferred that the concept of "concourse" is only acceptable in cases of total loss of organ functions (total permanent blindness in conjunction with substantial weakening of ancillary organ system). Although in agreement with the assertion that "concourse" between different organ systems can only be affirmed in cases of major impairment, the author believes that the above cited criteria are overly restrictive.

In conclusion, the author finds it desirable that the war pension framework, as praiseworthy and valuable as it undoubtedly is will not fall by the wayside, much like a glorious, blighted monument forsaken and left uncared for. Four decades after 1978, interventions aimed at renewing and updating the system are certainly warranted and inescapable, so as to keep such an invaluable diagnostic-assessing tool perfectly operative, in order to best serve its paramount institutional and socioeconomic functions and continue to provide essential training for generation of forensic doctors, both civilian and military, as it has for decades.

\section{References}

ANTONIOTTI F., DI LUCA N.M., Osservazioni medico-legali sul D.P.R. 23 dicembre 1978, n. 915, in materia di pensioni di guerra., in «Zacchia», 54: 391, 1979.

ANTONIOTTI F. DE TULLIO O., DI LUCA N.M., La causa di servizio, l'equo indennizzo e l'azione di risarcimento dei pubblici dipendenti, Giuffrè, Milano, $1989^{3}$.

BISOGNI K., DE ROSA C., RICCI P., Causa di servizio. Evoluzione legislativa, giudizio medico legale, procedure, Youcanprint, Roma, 2015.

CASTRICA R., BOLINO G., I trattamenti pensionistici privilegiati e l'equo indennizzo, Giuffrè, Milano, 1999.

DI PASSIO R., Equo indennizzo e pensionamento privilegiato e normale dei dipendenti pubblici, Maggioli, $2009^{7}$.

FERRARI G., L'invalidità per causa di servizio e l'equo indennizzo nel pubblico impiego, Giuffrè, Milano, $2007^{3}$.

GROPPALI A., Le pensioni di guerra, Fratelli Treves, 1916.

MORELLI G.A., Le pensioni di guerra, Unione tipograficoeditrice torinese, 1920.

TORRI G., Le pensioni privilegiate di guerra: manuale teoricopratico con note di giurisprudenza ministeriale e legislazione coordinata, Stracca, 1922.
4 Cfr. Antoniotti F. de Tullio O., di Luca N. M., La causa di servizio, l'equo indennizzo e l'azione di risarcimento dei pubblici dipendenti, Giuffrè, Milano, 1989, p. 174 e gg.

5 D.M. 5 febbraio 1992 (Enactment of new pension schemes designed to provide impairment percentiles in order to grade disabilities and crippling diseases). 